\title{
comparison of Rumen Fermentation Parameters in Domestic Fed on Corn-Cob Based and Dry Cocoa Leaf-Based Complete Feed
}

\author{
${ }^{1}$ Irmayanti, ${ }^{2}$ Asmuddin Natsir, ${ }^{3}$ Sudirman Baco \\ ${ }^{1}$ Postgraduate student, Faculty of Animal Science, Hasanuddin University, Makassar, Indonesia \\ ${ }^{2}$ Animal Nutrition Department, Faculty of Animal Science, Hasanuddin University, Makassar, Indonesia \\ ${ }^{3}$ Animal Production Department, Faculty of Animal Science, Hasanuddin University, Makassar, Indonesia
}

Correspondence Author: Irmayanti, Postgraduate student, Faculty of Animal Science, Hasanuddin University, Makassar, Indonesia Email: irmayantisidam@gmail.com

Received date: 28 August 2019, Accepted date: 2 December 2019, Online date: 20 December 2019

Copyright: (C) 2019 Irmayanti et al., This is an open-access article distributed under the terms of the Creative Commons Attribution License, which permits unrestricted use, distribution, and reproduction in any medium, provided the original author and source are credited.

\begin{abstract}
The aim of this study was to analyse the rumen fermentation parameters in domestic goats (Capra aegagrus hircus) treated with complete feed made from corn cob and dry cocoa leaves. This research was conducted in December 2018 - January 2019.The data was assessedusing independent sample $T$-test at significance level of $5 \%$. Two experimental diets were prepared, i.e. corn cob ration (P1) and dry cocoa leaf ration (P2), and 5 replications. The effect of these diets on characteristicsof rumen fermentation was investigated, including $\mathrm{pH}$, level of $\mathrm{NH}_{3}$ and VFA. The results showed that both diets did not exhibit significant difference $(\mathrm{P}>0,05)$ on $\mathrm{pH}\left(6,38 \pm 0,28\right.$ for $\mathrm{P} 1$ and $(6,61 \pm 0,32$ for $\mathrm{P} 2)$, level of $\mathrm{NH}_{3}(7,16 \pm 2,57$ for $\mathrm{P} 1$ and $8,16 \pm$ $1,78$ for P2), and VFA (109,76 $\pm 37,41$ for $P 1$ and $108,89 \pm 41,56$ for $P 2)$. Our experimental results suggested that corn cob in the diet could be replaced by dry cocoa leaves.
\end{abstract}

Keywords: dry cocoa leaf, domestic goat, rumen fermentation, complete feed, corn cob.

\section{INTRODUCTION}

Along with increasing demands for livestock products, goat meat has now been considered as an essential meat source. The feed is an essential factor that determines the success of goat farming, since it determines the fulfillment of basic animal needs, including meat production and reproduction. In contrast, poor feeding is closely associated with loss of growth, manufacturing, and reproduction. For this reason, more attention needs to be given to the quantity and nutritional content offered. Hence, it is necessary to ensure that high-quality animal diets provided continuously.

A conventional goat diet can be either forage or complete feed containing forage and concentrate. Forage-based diet is often hindered due to seasonal fluctuations in availability. During the dry season in which forage is scarcely obtained, farmers need to find an alternative feed. To deal with this situation, the conversion of agricultural waste to feed can be promising, especially for livestock in tropical areas such as Indonesia. Dry cocoa leaves, abundant agricultural biomass, constitute an appreciable candidate as material for complete feed.

A complete feed is a mixture of forage and concentrate with a particular proportion and nutritional composition adjusted to animal requirements, and given to animals as a single diet [1]. This diet is prepared to enhance the valorization of agricultural and agroindustrial waste as materials for diets of ruminant animals through either physical treatments or feed supplementation. In this case, dry cocoa leaves are intended to convert as goat feed. Although the leaves are present in an abundant amount, they are still underutilized. Chemical composition of fresh cocoa leaves included dry matter $62,95 \%$, crude protein $7,65 \%$, crude fat $4,54 \%$ and crude fiber $47,12 \%$ [2]. Additionally, corn cob is also considered as a good candidate for ruminant animal feed. To date, it is still not widely processed into valuable products. In terms of chemical composition, [3] reported that corn cob contained crude fiber $35,5 \%$, protein $2,5 \%$, calcium $0,12 \%$, phosphor $0,04 \%$ and other substances $38,16 \%$.

Based on the aforementioned elaboration, we proposed an in vivo experiment to investigate the fermentability of corn cob-based feed and dry cocoa leaf-based feed for domestic goats. The research is expected to provide beneficial information for further use of corn cob and dry cocoa leaves as a source of fiber in complete feed.

\section{MATERIALS AND METHODS}




\section{Time And Location}

This research was conducted in December 2018 - January 2019. The in vivo experiment was performed in the feed test laboratory, while rumen analysis was carried out in the laboratory of feed chemistry, Faculty of Animal Science, Hasanuddin University.

\section{Preparation of complete feed}

The complete feed (containing crude protein 10\%) was prepared from the dry cocoa leaf or corn cob, rice bran, molasses, soy pulp (solid waste of tofu industry), milled corn, urea, salt, and mineral. Dry cocoa leaves were chopped and mixed with other materials to obtain a homogenous mixture. The mixture was stored under the anaerobic condition at room temperature. Meanwhile, corn cob-based complete feed was also made with a similar method as mentioned in dry cocoa leaf-based complete feed. Material composition in making complete rations can be seen in table.1.

Table 1: Material composition in making complete feed

\begin{tabular}{|c|c|c|c|c|c|c|}
\hline \multirow{2}{*}{ Komposisi } & $\boldsymbol{\%}^{2}$ Material & \multicolumn{2}{|c|}{ Crude Protein Formulation Levels (\%) } & \% As Feed \\
\cline { 2 - 7 } & $\mathbf{P}_{\mathbf{1}}$ & $\mathbf{P}_{\mathbf{2}}$ & $\mathbf{P}_{\mathbf{1}}$ & $\mathbf{P}_{\mathbf{2}}$ & $\mathbf{P}_{\mathbf{1}}$ & $\mathbf{P}_{\mathbf{2}}$ \\
\hline Corn cob & 45 & - & 1,12 & - & 35,46 & - \\
\hline Dry cocoa leaf & - & 45 & - & 2,7 & - & 35,71 \\
\hline Rice bran & 30 & 30 & 2,46 & 2,54 & 22,66 & 22,55 \\
\hline Milled corn & 13 & 13,5 & 1,4 & 1,35 & 10,25 & 10,59 \\
\hline Soy pulp & 2,5 & 2,5 & 0,76 & 0,75 & 17,13 & 17,05 \\
\hline Molasses & 5 & 5 & 0,42 & 0,41 & 11,42 & 11,37 \\
\hline Mineral & 2 & 2 & 0 & 0 & 1,37 & 1,36 \\
\hline Urea & 1,5 & 1 & 4,30 & 0 & 1,03 & 0,68 \\
\hline Salt & 1 & 1 & 0 & 10,66 & 0,69 & 0,68 \\
\hline & 100 & 100 & 10,46 & & 100 & 100 \\
\hline
\end{tabular}

Information: P1 = Corn cob based complete feed

$\mathrm{P} 2$ = Dry cocoa leaf-based complete feed

\section{In vivo experiment}

The complete feed was then administered to 10 female domestic goats (average age of \pm 1 year, the weight of 9-14 kg). In this part, characteristics of rumen fermentation were observed, i.e. $\mathrm{pH}, \mathrm{NH}_{3}$, and volatile fatty acid (VFA). The $\mathrm{pH}$ was measured by $\mathrm{pH}$ meters and $\mathrm{NH}_{3}$ was analyzed using the Conway micro diffusion method.

The concentration of $\mathrm{NH}_{3}$ was calculated as follows:

$\mathrm{NH}_{3}=\left(\mathrm{ml} \mathrm{H}_{2} \mathrm{SO}_{4}\right.$ titrated $\left.\times \mathrm{N} \mathrm{H}_{2} \mathrm{SO}_{4} \times 1000\right) \mathrm{mM}$.

Total VFA was determined using steam distillation, and calculated as follows:

Total VFA $=($ Vol. Blank solution - Vol. sample titrated $) \times \mathrm{N} \mathrm{HCl} \times 1000 / 5 \mathrm{mM}$

Statistical Analysis

Statistical analysis makes use of independent sample T-test at the significance level of 5\% was used to evaluate the experimental data, obtained from 2 treatments (P1 and P2) and 5 replications.

\section{RESULTS AND DISCUSSION}

As important part of the digestive system of ruminant animals, rumen condition is essential since digestion of feed occurs here. The digestive system closely relates to the role of microbes in rumen, capable of facilitating absorption and generation of nutrition and energy for the host. The condition of rumen fermentation in goat was depicted in Table 2. Statistical analysis showed that the characteristics of rumen fermentation $\left(\mathrm{pH}, \mathrm{NH}_{3}, \mathrm{VFA}\right)$ did not differ significantly between domestic goats fed corn cob- and dry cocoa leaf-based complete diets $(\mathrm{P}>0,05)$.

Table 2: Average level of $\mathrm{pH}, \mathrm{NH}_{3}$ and VFA in rumen liquid of the experimental goats

\begin{tabular}{|c|c|c|}
\hline \multirow{2}{*}{ Parameters } & \multicolumn{2}{|c|}{ Treatments } \\
\cline { 2 - 3 } & $\mathbf{P 1}$ & $\mathbf{P 2}$ \\
\hline $\mathrm{Ph}$ & $6,38 \pm 0,28$ & $6,61 \pm 0,32$ \\
\hline $\mathrm{NH}_{3}(\mathrm{mM})$ & $7,16 \pm 2,57$ & $8,16 \pm 1,78$ \\
\hline $\mathrm{VFA}(\mathrm{mM})$ & $109,76 \pm 37,41$ & $108,89 \pm 41,56$ \\
\hline
\end{tabular}

Information: P1 = Provision of corn cobs based complete feed

$\mathrm{P} 2$ = Provision of dry cocoa leaf-based full feed

The level of $\mathrm{pH}$ serves as an essential factor in the activation of microorganisms under anaerobic conditions. It remarkably affects the microbial population present in rumen. As shown in Table1, the pH level found in P1 and P2 did not differ significantly $(\mathrm{P}>0,05)$. Rumen liquid was sampled $4-5$ hours after feeding. As presented, $\mathrm{pH}$ value in $\mathrm{P} 2$ treatment $(6,61)$ was 
slightly lower than in P1 treatment (6,38), but this condition was still acceptable for microbial growth in the rumen. [4] reported that the ideal level of $\mathrm{pH}$ in fiber digestion ranged from 6,3 to 7,0. This means that the condition enables to promote optimum health for fiber digestion and activity of cellulolytic bacteria. Additionally, [5] found that the optimum level of $\mathrm{pH}$ in sheep and goat was from 5 to 6,85 , while at low $\mathrm{pH}$, the activity of cellulolytic bacteria may be inhibited, which can cause detrimental effects on rumen in the digestive system. Such conditions may occur at a $\mathrm{pH}$ level of 6,0 - 6,2 [4]. The pH level in rumen represents a balance between buffering capacity and alkaline/acid condition (due to presence fermentation product) acting as a buffer against VFA generated by fermentative bacteria. This acidity was influenced by physical properties, types, and chemical composition of the ingested feed. Feed rich in fiber or polysaccharide tended to cause a pH level of 7,5; but, the high content of starch or easy-to-dissolve carbohydrate could lower $\mathrm{pH}$ level up to 5,0 [6].

Similarly, the concentration of $\mathrm{NH}_{3}$ did not differ significantly between $\mathrm{P} 1$ and $\mathrm{P} 2(\mathrm{P}>0.05)$. We found that $\mathrm{NH}_{3}$ in $\mathrm{P} 2$ $(8,16 \mathrm{mM})$, was slightly higher than that in $\mathrm{P} 1(7,16 \mathrm{mM})$, with both levels still within the optimal range to support microbial growth in the rumen. The optimal $\mathrm{NH}_{3}$ levels required to synthesize microbial protein is $5-20 \mathrm{mg} / \mathrm{dl}$, which is equal to 3,57-14,28 $\mathrm{mM}$ [7]. [4] Reported that $\mathrm{NH}_{3}$ levels lower than 3,57 mM could cause inhibition of microbial growth in the rumen. Our result suggested that the formulated diets enabled to serve as a source of nitrogen and carbon in line with microbial needs. Therefore, both diets (P1 and P2) showed equal effects on the formation of ammonia as a source of nitrogen. Our data showed that the $\mathrm{NH}_{3}$ level was higher than that obtained by [8] estimating the $\mathrm{NH}_{3}$ concentration up to 3,60 - 3,81 mM. In addition, [9] reported that the strength of $\mathrm{NH}_{3}$ after treatment with rice straw-based complete feed was 3,27-3,57 mM. Furthermore, the concentration of $\mathrm{NH}_{3}$ was significantly influenced by the degradation of crude protein in the rumen. $\mathrm{NH}_{3}$ level increases as more crude protein are hydrolyzed; thus, its level positively relates to the degree of crude protein hydrolysis, as also reported by[10].

The results demonstrated that VFA levels between P1 and P2 did not differ significantly (P>0,05). The VFA concentration in goat fed dry cocoa leaf ration reached $108,89 \mathrm{mM}$, which was lower than that in goat fed corn cob ration (109,76 mM). Both levels fall within the normal range of VFA production. [11] reported that the desirable level of VFA for the growth of rumen microbes was 80 - $160 \mathrm{mM}$. It is noticeable that concentration of VFA depends on feed fermentability, amount of soluble carbohydrate, $\mathrm{pH}$ level, feed digestibility, amount of feed, feed form, level and frequency of feeding, feed processing, and types of bacteria in the rumen[12]. A study on rice straw-based diet by [9] found higher VFA levels of 110,00 - 122,50 mM. As mentioned, VFA production could be influenced by microbe composition in the rumen. Higher VFA levels could indicate the fermentability of chemicals (carbohydrate and protein) in feed by rumen microorganisms. The high solubility of the protein in feed tends to raise its fermentability, leading to an increase in the production of VFA and ammonia. In short, VFA concentration is positively associated with the availability of soluble protein and carbohydrates. Noticeably, higher VFA levels contributed to optimal energy supply, indicating that fermentation process occurred effectively [13]

\section{CONCLUSION}

Our experimental data demonstrated that both studied diets (corn cob-based complete feed, dry cocoa leaf-based complete feed) did not produce a significant difference in characteristics of rumen fermentation in domestic goat.

\section{REFERENCES}

[1] Maryono, 2006. Teknologi Inovasi Pakan Murah untuk Usaha Pembibitan Sapi Potong Lokal.Sinar Tani Edisi 18-24 Oktober 2006.

[2] Gunawan, D. E. Wahyono, dan P. W. Prihandini. 2003. Strategi penyusunan pakan murah sapi potong untuk mendukung berkembangnya agribisnis. Prosiding loka karya nasional sistem integrasi kelapa Sawit-Sapi. Bengkulu, 9-10 September 2003. Puslitbangnak bekerja sama dengan Pemerintah Provinsi Bengkulu dan PT Agricinal. Bogor.

[3] Maynard, L. A. dan J. K. Loosli. 1993. Animal Nutrition. Seventh Edition. Hill Publishing Company Limited. New Delhi.

[4] Kaunang, C. L. 2004. Uji In Vivo Silase Hijauan Pakan yang Dipupuk Kandang dan Air Belerang pada Domba. Tesis S-2. Program Pasca Sarjana Institut Pertanian Bogor.

[5] Hriston, A. N., J. K. Ropp, K. L. Grandeen, S. Abadi, R.P. Etter, A, Melgar, and A. E. Foley. 2009. Effect of carbohydrate source on ammonia utilization in lactating dairy cows. Department of Animal and Veterinary Science, University of Idaho, 83844-2330.

[6] Theodorou, M. K., B. A. Williams, M. S. Dhanoa, A. D. B. McAlan, and J. France. 1994. A simple gas production method using a pressure transducer to determine the fermentation kinetics of ruminant feeds. Anim. Feed Sci. Technol., 48:185-197.

[7] Paengkoum, P., Liang, J.B., Jelan, Z.A., and Basery, M. 2006. Utilization of Steam-treated Oil Palm Fronds in Growing Saanen Goats: II. Supplementation with Energy and Urea. Asian-Aust. J. Anim. Sci. 19 (11):1623-1631.

[8] Aswandi, C. I. Sutrisno, M. Arifin, dan A. Joelal. 2012. Efek complete feed bonggol berbagai varietas tanaman pisang terhadap $\mathrm{pH}, \mathrm{NH} 3$ dan VFA pada kambing kacang. (Effect of complete feed containing starch tubers of different varieties of banana plants on $\mathrm{pH}, \mathrm{NH} 3$ and VFA of kacang goat). Agricultural Counselling College of Manokwari, Doctoral Program Animal Sciences, University of Diponegoro. JITP Vol. 2 No. 2. 
[9] Widodo, F., Wahyono, dan Sutrisno. 2012. Kecernaan Bahan Kering, Kecernaan Bahan Organik, Produksi VFA dan NH3 Pakan Komplit dengan Level Jerami Padi Berbeda secara in Vitro. Animal Agricultural Journal, Fakultas Peternakan dan Pertanian Universitas Diponegoro. Semarang., 1(1):215-230.

[10] Cahyani, R.D., Nuswantoro, L.K. dan Subrata, A., 2012 Pengaruh proteksi protein tepung kedelai dengan tannin daun bakau terhadap konsentrasi amonia, undergraded protein dan protein total secara in Vitro. J. Anim. Agric 1(1):159- 166.

[11] Sutardi, T., N. A. Sigit dan T. Toharmat. 1983. Standarisasimutu protein bahan makanan ternak ruminansia, berdasarkan parameter metabolismenya oleh mikrobia rumen. Proyek Pengembangan Ilmu dan Teknologi. Ditjen Pendidikan Tinggi. Jakarta.

[12] Wijayanti, E., F. Wahyono dan Surono. 2012. Kecernaan nutrien dan fermentabilitas pakan komplit dengan level ampastebu yang berbeda secara in vitro. J. Anim. Agric. 1 (1):167 - 179.

[13] Sandi, S., A. I. M. Ali, dan A. A. Akbar. 2015. Uji in vitro wafer ransum komplit dengan bahan perekat yang berbeda. Jurnal Peternakan Sriwijaya. 4 (2):7 - 16. 